\title{
Profitabilitas Pemoderasi Determinan Pengungkapan Modal Intelektual
}

\author{
Hasan Mukhibad ${ }^{1}$ \\ Meyliani Eka Setyawati \\ ${ }^{1,2}$ Fakultas Ekonomi dan Bisnis, Universitas Negeri Semarang, Indonesia \\ email : hasanmukhibad@mail.unnes.ac.id
}

DOI: https://doi.org/10.24843/JIAB.2019.v14.i01.p11

\section{Jurnal Ilmiah Akuntansi dan Bisnis (JIAB)}

https://ojs.unud.ac.id/index.php/jiab/ user/profile

Volume 14

Nomor 1

Januari 2019

Halaman 120-131

p-ISSN $\underline{2302-514 X}$

e-ISSN $\underline{2303-1018}$

\section{INFORMASI ARTIKEL}

Tanggal masuk:

21 Juni 2018

Tanggal revisi:

18 Januari 2019

Tanggal diterima:

21 Januari 2019

\begin{abstract}
ABSTRAK
Tujuan penelitian adalah membuktikan secara empiris pengaruh umur, kepemilikan manajerial, ukuran, dan leverage pada perusahaan LQ45 terhadap Intellectual Capital Disclosure (ICD) dengan profitabilitas sebagai variabel moderating. Penelitian menggunakan metode purposive sampling dalam menentukan sampel dengan tahun pengamatan 2014-2017. Sampel penelitian sebanyak 26 perusahaan dengan 104 unit analisis. Metode analisis data menggunakan analisis regresi moderasi dengan uji nilai selisih mutlak. Hasil penelitian memberikan bukti empiris bahwa umur perusahaan, ukuran perusahaan dan rasio kepemilikan manajerial memiliki dampak positif terhadap ICD. Tingkat leverage tidak memiliki dampak terhadap ICD. Selain itu, hasil penelitian juga menunjukkan bahwa profitabilitas hanya mampu memperkuat pengaruh ukuran perusahaan dengan pengungkapan ICD dan memperlemah pengaruh kepemilikan manajerial terhadap ICD. Profitabilitas tidak memoderasi hubungan antara umur, dan leverage terhadap ICD.
\end{abstract}

Kata Kunci: Kepemilikan manajerial, earning per share, leverage, intellectual capital disclosure.

\section{Intellectual Capital Determinants with Profitability as Moderating Variable \\ ABSTRACT}

This research aims to analyze the effect of age, size, managerial ownership, and leverage on Intellectual Capital Disclosure (ICD) with earnings per share as a moderating variable. The population of this research is companies listed on the LQ 45 Index. The sampling method used to determine the samples of this research is purposive sampling, in the observation year 2014-2017. The research samples are 26 companies with 104 units of analysis. The data are then analyzed using moderation regression analysis with the absolute difference value test. The results are indicate that age, size, and managerial ownership have a positive effects on ICD, while the leverage does not. Further, companies' profitability could strengthen the correlation between size and ICD but weaken toward the correlation between managerial ownership and ICD.

Keywords: Managerial ownership, financial performance, leverage, disclosure of intellectual capital. 


\section{PENDAHULUAN}

Pada era globalisasi, perusahaan diharapkan dapat memiliki kemampuan untuk cepat beradaptasi dalam menghadapi perubahaan di era digitalisasi dan kondisi ekonomi global. Robert \& Angelo (2014) mengutip penelitian Hudson Institute dalam bukunya Workforce 2020 bahwa salah satu tantangan yang dihadapi oleh organisasi adalah pergeseran dari bidang pekerjaan manufaktur dan petanian menjadi bidang industri jenis pelayanan dan telekomunikasi. Situasi ini muncul karena proses globalisasi dan juga karena peningkatan terobosan di berbagai bidang seperti teknologi produksi, komputasi dan telekomunikasi (Osinski et al., 2017).

Konsekuensi logis dari keadaan ini adalah timbulnya pergeseran dari asset tradisional menjadi intellectual capital (IC) (Camfield, et al,. 2018). Modal intelektual adalah aset non-tradisional, tidak berwujud; dan akumulasi, transformasi, dan penilaiannya terletak pada inti manajemen pengetahuan (Firer \& Williams, 2005). Seetharaman, et al. (2002) mengungkapkan bahwa pengungkapan modal intelektual merupakan konsekuensi dari masuknya industri menuju ke area berbasis pengetahuan. Aset berwujud ini untuk memberikan nilai tambah (value added) dan mampu mendukung keberhasilan perusahaan. Manfaat dari IC adalah mampu memberikan peran yang signifikan dalam meningkatkan kinerja perusahaan. (Chahal \& Bakshi, 2016; Chu, et al., 2011; Clarke, et al., 2010; Sardo \& Serrasqueiro, 2018; Sumedrea, 2013; Ting \& Lean, 2009; Zehri, et al., 2012) dalam penelitiannya telah membuktikan secara empiris bahwa IC mampu meningkatkan kinerja perusahaan.

Manfaat lainnya adalah IC mampu memberikan potensi pertumbuhan perusahaan. Akibatnya, perusahaan yang memiliki IC yang tinggi akan dapat meningkatkan keberlangsungan usaha perusahaan (Chahal \& Bakshi, 2016; Sudibyo \& Basuki, 2017). Hal ini disebabkan pada era pergeseram model pengelolaan perusahaan yang berorientasi pada knowledge-based economy, kunci utama perusahaan bukan berada pada set secara fisik namun berdasarkan aset yang berbasis knowledge (Sudibyo \& Basuki, 2017; Noradiva et al., 2016). Dengan demikian modal intelektual telah menjadi sumberdaya yang fundamental untuk keberhasilan perusahaan (Bontis, et al., 2015).

Selain itu, perusahaan yang mengungkapkan modal intelektual dapat mengurangi asimetri informasi (Bhasin, 2011; Kateb, 2014), meningkatkan likuiditas pasar saham (Gheisari \& Amozesh, 2016), kapitalisasi pasar (Abdolmohammadi, 2005), dan meningkatkan permintaan jumlah saham. Sementara itu perusahaan yang tidak mengungkapkan modal intelektual akan memiliki dampak buruk terhadap kualitas keputusan yang dibuat oleh pemegang saham. Hal ini disebabkan karena adanya perkembangan bahwa informasi modal intelektual yang awalnya digunakan untuk tujuan manajemen menjadi fokus pada pemangku kepentingan (eksternal). Suwarjuwono \& Kadir (2003) menegaskan bahwa informasi modal intelektual yang tidak diungkapkan dapat menyesatkan para pengguna laporan keuangan.

Pentingnya IC yang memiliki efek positif terhadap kinerja profitabilitas dan peningkatan keberlangsungan usaha perusahaan ini belum mampu diimplementasikan oleh perusahaan di Indonesia. Data dari penelitian terdahulu menunjukkan rata-rata pengungkapan modal intelektual perusahaan di Indonesia masih rendah. Nilai rata-rata pengungkapan yang sama terjadi pada perusahaan perbankan yang terdaftar di Bursa Efek Indonesia (BEI) sebesar 36,38\% (Utama \& Khafid, 2015). Meizaroh \& Lucyanda (2012) menemukan nilai ratarata pengungkapan IC sebesar $23,81 \%$ pada perusahaan yang terdaftar di BEI. Lebih lanjut, Setianto \& Purwanto (2014) menemukan bahwa nilai rata-rata sebesar $25,16 \%$ pada perusahaan yang terdaftar Indeks Kompas 100.

Dari beberapa penelitian sebelumnya, seperti Abdolmohammadi (2005); Gheisari \& Amozesh (2016); Suparno \& Ramadini (2017); Utami (2018); W \& Firmansyah (2012); Wedari (2016); Yudhanti \& Shanti (2011) telah meneliti IC dengan menggunakan perusahaan LQ45 sebagai obyek penelitiannya. Namun demikian, perbedaan utama penelitian ini dengan penelitian sebelumnya adalah pengukuran IC berdasarkan pengungkapan dan profitabilitas yang diukur dengan EPS sebagai variabel moderator. Pemilihan metode pengukuran ini didasarkan pada alasan bahwa salah satu pengguna laporan tahunan yang didalamnya memuat informasi IC adalah investor, sehingga pengukuran profitabilitas lebih menggunakan laba yang disesuaikan dengan harga saham.

Penelitian ini dilakukan untuk menganalisis faktor-faktor yang mempengaruhi perusahaan dalam melakukan pengungkapan modal intelektual. Dalam penelitian ini, variabel umur perusahaan, ukuran perusahaan, kepemilikan manajerial, dan leverage 
sebagai variabel independen dalam mengungkapkan modal intelektual. Alasan penggunaan umur perusahaan dan jumlah aset sebagai variabel yang mempengaruhi pengungkapan IC adalah berdasarkan teori stakeholders, manajemen akan berupaya untuk memenuhi kepentingan stakeholders dengan melakukan pengungkapan yang berlebih, termasuk pengungkapan IC. Perusahaan yang sudah lama berdiri dan memiliki aset yang besar, dan mengindentifikasikan perusahaan tersebut memiliki stakeholder yang besar. Stakeholder yang besar akan meningkatkan dorongan manajemen untuk melakukan pengungkapan IC. Mariana, et al. (2011), Yosano (2009), Harianto (2012), Lina (2013), Asfahani (2017), dan Reditha \& Mayangsari (2016) telah membuktikan bahwa umur perusahaan memiliki pengaruh positif terhadap pengungkapan IC. Sementara itu Brüggen, et al., (2009); Eddine, et al. (2015); dan Taliyang, et al., (2011) menemukan bahwa jumlah aset memiliki pengaruh positif terhadap pengungkapan IC. Dengan demikian, dapat dikembangkan hipotesis berikut ini:

$\mathrm{H}_{1}$ : Umur perusahaan memiliki pengaruh positif terhadap pengungkapan modal intelektual

$\mathrm{H}_{2}$ : Jumlah aset memiliki pengaruh positif terhadap pengungkapan modal intelektual

Pengungkapan IC juga dipengaruhi secara positif oleh kepemilikan manajemen. Firer \& Williams (2005) menemukan bahwa struktur kepemilikan perusahaan memiliki pengaruh pada pengungkapan intangible. Lebih spesifik, Hidalgo, et al., (2011) dan Mukti \& Istianingshih (2018) menemukan bahwa kepemilikan institusional mempengaruhi pengungkapan IC. Hidalgo et al., (2011) tidak ada pengaruh antara kepemilikan keluarga, dan direktur terhadap pengungkapan IC. Penelitian ini menduga bahwa kebutuhan pengungkapan IC oleh stakeholders akan semakin mudah diakomodir oleh manajemen jika terdapat manajemen yang juga sebagai shareholders.

H3 : Rasio kepemilikan manajerial memiliki pengaruh positif terhadap pengungkapan modal intelektual

Perusahaan yang memiliki leverage yang tinggi akan berupaya semaksimal mungkin untuk meningkatkan kinerjanya. Peningkatan kinerja ini dibutuhkan untuk meningkatkan kapabilitas perusahaan untuk membayar hutang. Selain itu, kinerja yang baik juga akan meningkatkan kepercayaan investor terhadap perusahaan.
Peningkatan kinerja dapat dilakukan dengan peningkatan pengungkapan informasi kinerja, termasuk IC. Selain itu, peningkatan leverage juga mengindikasikan semakin besarnya dan kuatnya stakeholders atas perusahaan. Selain itu, pengungkapan intelektual akan meminimalisasi biaya monitoring kreditur, sehingga pengungkapan IC dapat mengurangi konflik keagenan (Woodcock \& Whiting, 2009). Mitra, et al., (2015) menemukan bahwa pengaruh leverage signifikan ditunjukkan dalam kaitannya dengan pengungkapan IC oleh perusahaan-perusahaan bioteknologi Inggris dan Australia. Dengan demikian dapat dikembangkan hipotesis:

$\mathrm{H}_{4}$ : Leverage memiliki pengaruh positif terhadap pengungkapan modal intelektual

Selain itu, novelty dalam penelitian ini adalah penggunaan variabel kinerja keuangan sebagai variabel moderating. Penggunaan variabel kinerja keuangan sebagai variabel moderating ini dilakukan dengan alasan pengungkapan informasi membutuhkan biaya, sehingga hanya perusahaan yang memiliki kinerja yang baik yang mampu melakukan pengungkapan, termasuk pengungkapan IC.

Selain itu, dari beberapa penelitian terdahulu, seperti Chahal \& Bakshi (2016); Chu, et al., (2011); Clarke, et al. (2010); Sardo \& Serrasqueiro (2018); Sumedrea (2013); Ting \& Lean (2009); Zehri, et al. (2012); dan Bidaki \& Hejazi, (2014) menggunakan variabel kinerja keuangan sebagai salah satu faktor yang mempengaruhi modal intelektual. Temuan di Indonesia terhadap ada atau tidak adanya pengaruh kinerja keuangan terhadap modal intelektual masih menghasilkan inkonsistensi. Yudhanti \& Shanti (2011); Bidaki \& Hejazi (2014) dan Suwart, et al. (2016) menemukan bahwa profitabilitas mempengaruhi pengungkapan modal intelektual. Sementara itu, Taliyang et al. (2011); Asfahani (2017); Anderrson \& Folkare (2015) Hrp, et al. (2018); Maulida (2013) dan Kateb (2014) menemukan bahwa profitabilitas tidak mempengaruhi modal intelektual. Ketidak konsistensi hasil penelitian di atas, terdapat potensi adanya dugaan bahwa kinerja keuangan sebagai salah satu penyebab (namun tidak langsung) perusahaan melakukan pengungkapan modal intelektual. Sehingga dalam penelitian ini, variable kinerja keuangan digunakan sebagai variabel moderating. Dengan demikian, dapat dikembangkan hipotesis: 
$\mathrm{H}_{5}$ : Profitabilitas memperkuat pengaruh umur perusahaan terhadap pengungkapan modal intelektual

$\mathrm{H}_{6}$ : Profitabilitas memperkuat pengaruh aset terhadap pengungkapan modal intelektual

$\mathrm{H}_{7}$ : Profitabilitas memperkuat pengaruh kepemilikan manajemen terhadap pengungkapan modal intelektual

$\mathrm{H}_{8}$ : Profitabilitas memperlemah pengaruh leverage terhadap pengungkapan modal intelektual

\section{METODE PENELITIAN}

Perusahaan yang termasuk Indeks LQ 45 dipilih sebagai populasi penelitian dengan pengamatan selama tahun 2014 sampai dengan 2017. Sampel ditentukan dengan menggunakan purposive sampling method dan menghasilkan 26 perusahaan dengan 104 unit analisis. Alat uji untuk menentukan penerimaan atau penolakan terhadap hipotesis yang dikembangkan dalam penelitian ini menggunakan analisis regresi berganda dan uji nilai selisih mutlak untuk menentukan alat uji moderasi.

Pengukuran variabel pengungkapan IC diukur dengan menggunakan persentase pengungkapan indikator human capital, structural capital, dan relational capital (33 item). Setiap indikator yang diungkapkan oleh perusahaan akan dinilai 1 dan sebaliknya jika tidak diungkapkan akan dinilai nol. Nilai IC diukur dengan jumlah skore dibagi dengan jumlah maksimal skor. Umur perusahaan diukur dengan tahun perusahaan beroperasi sampai pada tahun pengamatan. Ukuran perusahaan menggambarkan besar kecilnya perusahaan yang diukur dengan berdasarkan jumlah aset. Kepemilikan manajerial merupakan persentase saham yang dimiliki oleh manajemen. Leverage diukur dengan rasio kewajiban terhadap total ekuitas (Debt to Equity Ratio - DER). Profitabilitas diukur dengan menggunakan indikator earning per share (EPS) dimana EPS diukur dengan menggunakan rasio laba bersih terhadap jumlah saham beredar. Pemilihan dalam penggunaan DER sebagai indikator dalam mengukur leverage dan EPS sebagai indikator profitabilitas di sebabkan karena obyek penelitian ini adalah perusahaan LQ45, sehingga pemilihan indikator DER dan EPS adalah tepat. Karena indikator DER dan EPS adalah indikator yang sudah disesuaikan dengan kapitalisasi pasar saham perusahaan.

Sebelum dilakukan uji regresi dan analisis selisih mutlak, data akan dilakukan pengujian asumsi klasik (normalitas, heteroskedastisitas, dan multikolonieritas). Analisis selisih mtlak adalah metode pengujian dengan meregresikan variabel bebas dengan variabel modertasi terstandarisasi dengan melihat selisih mutlaknya. Tingkat signifikansi yang digunakan adalah $5 \%$ dan $10 \%$.

\section{HASIL DAN PEMBAHASAN}

Analisis statistik deskriptif digambarkan nilai rata-rata (mean), standar deviasi, nilai maksimum dan minimum dan tersaji pada Tabel 1 berikut ini.

Tabel 1. Statistik Deskriptif

\begin{tabular}{llrrrr}
\hline & N & \multicolumn{1}{l}{ Min } & \multicolumn{1}{c}{ Maks } & \multicolumn{1}{c}{ Mean } & \multicolumn{1}{c}{ Std. Dev. } \\
\hline ICD & 104 & 0,061 & 0,909 & 0,563 & 0,189 \\
AGE & 104 & 5,000 & 122,000 & 46,076 & 22,833 \\
SIZE & 104 & 29,789 & 34,657 & 31,440 & 1,271 \\
MANOWN & 104 & 0,000 & 0,007 & 0,001 & 0,001 \\
LEV & 104 & 0,1331 & 7,205 & 1,750 & 1,765 \\
EPS & 104 & 21,600 & 4030,000 & 564,689 & 747,824 \\
Valid & $\mathrm{N}$ & & & & \\
(listwise) & & & & & \\
\hline
\end{tabular}

Sumber: Data sekunder yang diolah, 2018

Tabel 1 menunjukkan bahwa rata-rata pengungkapan IC perusahaan yang terdaftar pada LQ45 adalah 56,35\%. Nilai pengungkapan IC ini tergolong masih kecil karena rata-rata usia perusahaan adalah 46,08 tahun. Nilai rata-rata asset obyek penelitian adalah Rp31,44 trilyun dengan ratarata kepemilikan manajemen $0,07 \%$. Dengan rata- rata kepemilikan manajemen sebesar 0,07\% ini menguatkan independensi dewan komisaris dalam melakukan pengawasan terhadap kinerja manajemen.

Hasil uji asumsi klasik menghasilkan nilai kolmogorov smirnov (K-S) sebesar 1,167 dan nilai asymp.sig (2-tailed) sebesar 0,131 atau di atas 
kepercayaan $\alpha=0,05$. Hasil ini menujukkan bahwa data residual terdistribusi normal. Uji heterokedastisitas menggunakan uji glejser dengan probabilitas signifikansi diatas tingkat kepercayaan 0,05 . Jadi dapat disimpulkan model regresi tidak mengandung adanya heteroskedastisitas. Uji multikolonieritas menghasilkan nilai tolerance $>0,10$ dan nilai VIF $<10$ serta korelasi antar variabel independen dibawah 0,90 sehingga dapat disimpulkan tidak terjadi multikolonieritas antar variabel independen.

Uji autokorelasi menggunakan uji CohraneOrcutt Step 2 untuk mengatasi masalah autokorelasi yang menunjukkan nilai DW 1,909 lebih besar dari batas atas (du) 1,7508 dan kurang dari 4 - 1,7508 (4 - du), maka dapat disimpulkan bahwa tidak ada masalah autokorelasi. Hasil uji asumsi klasik menunjukkan bahwa model regresi dapat digunakan untuk menguji pengaruh umur perusahaan, ukuran perusahaan, kepemilikan manajerial, dan leverage terhadap pengungkapan modal intelelektual dan earning per share sebagai variabel moderating.

Hasil uji penerimaan atau penolakan hipotesis yang menggunakan regresi berganda dan analisis selisih mutlak menghasilkan temuan sebagai berikut ini:

Tabel 2. Hasil Pengujian Hipotesis

\begin{tabular}{clccc}
\hline No & \multicolumn{1}{c}{ Hipotesis } & Koef. Regresi & Sig. & Hasil \\
\hline 1 & $\begin{array}{l}\text { Umur perusahaan memiliki pengaruh positif terhadap } \\
\text { pengungkapan modal intelektual }\end{array}$ & 0,061 & 0,001 & Diterima* \\
2 & $\begin{array}{l}\text { Ukuran perusahaan memiliki pengaruh positif terhadap } \\
\text { pengungkapan modal intelektual }\end{array}$ & 0,173 & 0,000 & Diterima* \\
3 & $\begin{array}{l}\text { Rasio kepemilikan manajerial memiliki pengaruh positif } \\
\text { terhadap pengungkapan modal intelektual }\end{array}$ & 0,464 & 0,071 & Diterima** \\
4 & $\begin{array}{l}\text { Leverage memiliki pengaruh positif terhadap } \\
\text { pengungkapan modal intelektual }\end{array}$ & 0,032 & 0,257 & Ditolak \\
5 & $\begin{array}{l}\text { Profitabilitas memoderasi pengaruh umur perusahaan } \\
\text { terhadap pengungkapan modal intelektual }\end{array}$ & 0,027 & 0,352 & Ditolak \\
6 & $\begin{array}{l}\text { Profitabilitas memoderasi pengaruh ukuran perusahaan } \\
\text { terhadap pengungkapan modal intelektual }\end{array}$ & 0,234 & 0,000 & Diterima* \\
7 & $\begin{array}{l}\text { Profitabilitas memoderasi pengaruh kepemilikan } \\
\text { manajerial terhadap pengungkapan modal intelektual }\end{array}$ & $-0,500$ & 0,078 & Diterima** \\
8 & $\begin{array}{l}\text { Profitabilitas memoderasi pengaruh leverage terhadap } \\
\text { pengungkapan modal intelektual }\end{array}$ & 0,077 & 0,110 & Ditolak \\
\hline
\end{tabular}

* Signifikan pada 5\%, ** Signifikan pada $10 \%$.

Tabel 2 menunjukkan bahwa umur perusahaan berpengaruh positif signifikan terhadap pengungkapan ICD. Temuan ini mengindikasikan bahwa faktor lamanya perusahaan beropereasi akan memiliki pada berdampak pada perusahaan dalam mengungkapkan ICD. Hasil penelitian ini menguatkan hasil penelitian Mariana, et al(2011), Yosano (2009), Harianto (2012), Lina (2013), Asfahani (2017), Reditha \& Mayangsari (2016) yang menemukan bahwa umur perusahaan berpengaruh positif terhadap pengungkapan ICD. Temuan ini mengindikasikan bahwa perusahaan yang sudah lama berdiri, memiliki kecenderungan yang lebih besar dalam mengungkapkan kinerjanya, termasuk pengungkapan dalam ICD. Hal ini dikarenakan perusahaan yang besar memiliki pengalaman dalam operasi dan penyusunan laporan kinerjanya.

Selain itu, berdasarkan konsep stakeholders theory, hasil penelitian ini menguatkan teori stakeholders. Perusahaan yang sudah lama berdiri akan memiliki jumlah aset dan stakeholders yang semakin besar. Sejalan dengan teori stakeholder bahwa semakin besar jumlah stakeholders-nya, perusahaan akan berusaha untuk memberikan yang terbaik bagi para stakeholder. Salah satu upaya adalah dengan memberikan informasi yang lebih lengkap daripada perusahaan lainnya, termasuk didalamnya adalah pengungkapan IC. Pengungkapan IC pada perusahaan di Indonesia masih bersifat sukarela (Asfahani; 2017), sehingga perusahaan yang memberikan pengungkapan IC, termasuk perusahaan yang memberikan informasi yang berlebih.

Dampak lain dari perusahaan yang sudah lama berdiri adalah memiliki kematangan dalam setiap setiap pengambilan keputusan perusahaan dalam mendukung keberhasilan perusahaan dalam mencapai tujuannya. Salah satu kepentingan stakeholders yang lebih besar adalah dengan 
dipenuhi dengan pemberian informasi kinerja yang lebih luas, salah satunya adalah informasi IC. Hal ini diperlukan karena dalam perusahaan yang besar, terdapat pemisahan tanggungjawab antara manajemen dan pemilik. Model pemisahan ini menyebabkan pemilik memiliki informasi kinerja yang lebih rendah daripada manajemen. Disisi lain, pemisahan tanggungjawan ini menyebabkan antara manajemen dan pemilik terjadi konflik keagenan dan salah satu usaha untuk mengurangi konflik ini adalah pengungkapan informasi yang lebih luas. (Firer \& Williams, 2005) mengungkapkan bahwa semakin lengkap pengungkapan atau informasi yang diberikan, akan semakin efektif principal dalam melakukan monitoring terhadap kinerja agent. Dengan demikian, pengungkapan IC dapat mengurangi asimetri informasi (Stropnik et al., 2017).

Ghozali \& Chariri (2014) menyatakan bahwa ketika stakeholder memiliki kendali yang kuat terhadap perusahaan, maka perusahaan akan bertindak dengan maksud memenuhi harapan para stakeholder. Salah satu kepentingan shareholders (bagian dari stakeholders) memiliki kepentingan terhadap perluasan informasi kinerja perusahaan, termasuk pengungkapan IC. Luasan pengungkapan yang dilakukan oleh perusahaan akan menurunkan asimateri informasi antara manajemen dan pemilik (Stropnik et al., 2017). Nuryaman (2009) menungkapkan bahwa tingginya asimetri informasi dapat meningkatkan biaya modal, selanjutnya akan berdampak pada penurunan harga saham perusahaan. Salah satu cara untuk mengurangi biaya modal tersebut adalah mendorong pihak manajemen untuk meningkatkan pengungkapan informasi, salah satunya adalah pengungkapan modal intelektual (Stropnik et al., 2017). Selain itu, perusahaan dapat mengungkapkan modal intelektual untuk menunjukkan sumber keunggulan kompetitif yang dimiliki kepada publik.

Hasil penelitian menunjukkan bahwa ukuran perusahaan memiliki pengaruh positif terhadap pengungkapan modal intelektual. Bastian (2006) mengungkapkan bahwa suatu entitas merupakan tempat atau titik pertemuan bagi berbagai jenis hubungan kontraktual antara stakeholders, yang meliputi manajemen, pemilik, kreditor, dan pemerintah. Dengan demikian, semakin besar ukuran perusahaan maka meningkatkan kompleksitas hubungan diantara stakeholders. Untuk menjamin kebutuhan informasi bagi para pemangku kepentingan, manajemen akan melakukan pengungkapan yang lebih tinggi, yakni dengan mengungkapkan modal intelektual.
Untuk memenuhi kepentingan stakeholders akan luasan informasi yang dibutuhkan, perusahaan membutuhkan biaya. Perusahaan yang memiliki asset yang besar, memiliki potensi sumber daya untuk melakukan pengungkapan yang besar. Lebih lanjut, Ousama, et al(2012) yang menyatakan bahwa perusahaan besar cenderung memiliki sumber daya untuk mengungkapkan informasi lebih lanjut, sehingga perusahaan yang besar memiliki kecenderungan mengadopsi sistem informasi manajemen internal yang lebih baik, sehingga mampu mengungkapkan informasi yang lebih lebih luas daripada peruahaan besar.

Hasil penelitian yang menunjukkan adanya pengaruh secara positif ukuran perusahaan terhadap ICD ini menguatkan hasil penelitian Brüggen et, al. (2009); Eddine et al. (2015); Taliyang et. al. (2011); Nuryaman (2009), Suhardjanto \& Wardhani (2010), Nany \& Mujiyono (2010), Branco, et al(2010), Ousama, et al(2012), Hrp et al., (2018); dan Sari \& Andayani (2017) yang menemukan bahwa ukuran perusahaan memiliki dampak positif terhadap pengungkapan IC. Namun demikian, hasil penelitian ini menolak hasil penelitian Priyanti \& Wahyudin (2015), Yosano (2009), Nugroho (2012), Ashari \& Putra (2016), Asfahani (2017) yang menemukan bahwa ukuran perusahaan tidak memiliki pengaruh terhadap pengungkapan IC.

Hasil penelitian ini juga memberikan bukti bahwa besaran kepemilikan manajerial tidak memiliki dampak positif terhadap pengungkapan IC. Hasil penelitian ini menguatkan temuan (Firer \& Williams, 2005); dan (Taliyang et al., 2011) dan menolak temuan Noradiva et, al. (2016). Pengambilan keputusan dalam perusahaan tentunya dipertimbangkan sesuai dengan keputusan pihak-pihak yang memiliki kendali yang signifikan dalam perusahaan. Pemilik mayoritas akan memiliki hak untuk memberikan andil yang cukup besar dalam setiap keputusan perusahaan. Keputusan yang diambil merupakan manifestasi dari berbagai informasi yang mendukung dan mampu menggambarkan sebenarnya kondisi perusahaan. Kepemilikan manajerial yang tinggi pada suatu perusahaan mengindikasikan bahwa direksi dan komisaris yang memiliki andil yang besar dengan dibuktikan saham yang dimiliki dalam perusahaan. Sesuai dengan teori stakeholder yang lebih memusatkan perhatian kepada para pemangku kepentingan yang memiliki pengaruh lebih besar terhadap kesuksesan perusahaan, maka peran serta manajemen dalam kepemilikan saham akan lebih kuat dalam melakukan monitoring dan pengungkapan 
informasi kinerjanya. Sesuai kondisi tersebut, pihak manajemen yang menjadi investor mayoritas akan meningkatkan pengungkapan informasi karena pengungkapan yang luas merupakan bentuk akuntabilitas yang tinggi yang dilakukan oleh manajemen kepada stakeholders perusahaan.

Selain itu, kepemilikan manajerial yang tinggi ini akan meningkatkan keselarasan kepentingan antara agent dan principal, akibatnya manajer akan melaksanakan kebijakan yang selaras dengan kepentingan pemilik (Jensen \& Meckling, 1976). Kondisi yang menyebabkan ketidaksamaan informasi yang terjadi antara agen dan prinsipal dapat diatasi, yakni salah satuya dengan mengungkapkan modal intelektual dalam laporan tahunan. Para ahli teori agensi berpendapat bahwa perusahaan dengan konsentrasi kepemilikan yang lebih besar mengungkapkan lebih banyak informasi untuk mengurangi biaya dan asimetri informasi (Firer \& Williams, 2005).

Disisi lain pihak manajemen ingin menunjukkan kepada publik atas kondisi perusahaan yang dikelolanya, sekaligus dapat memberikan informasi yang memadai untuk para pemangku kepentingan dalam rangka pengambilan keputusan. Hal ini didukung oleh pernyataan Prasinta (2012) yang mengungkapkan bahwa suatu perusahaan dengan manajemen yang baik akan memberikan perlindungan dan jaminan hak kepada para stakeholder, sehingga manajemen memiliki kewajiban memberikan informasi akurat sesuai dengan realitas yang dihasilkan oleh perusahaan.

Penelitian ini juga membuktikan bahwa tingkat leverage tidak memiliki dampak pada pengungkapan IC. Hasil penelitian ini menguatkan temuan Hrp et al., (2018); Boujelbene \& Affes (2013); Woodcock \& Whiting, (2009); Hidalgo et al., (2011); dan Taliyang et al., (2011) yang menemukan tidak terdapat hubungan antara leverage dengan pengungkapan IC. Selain itu, penelitian ini menolak hasil penelitian Eddine, et al(2015), Utama \& Khafid (2015), Asfahani (2017), Meizaroh \& Lucyanda (2012) mengungkapkan bahwa perusahaan dengan utang yang lebih tinggi diharapkan untuk mengungkapkan modal intelektual. Perusahaan dengan tingkat leverage yang tinggi akan berdampak pada semakin tingginya perhatian kreditur atas pinjaman yang telah diberikan. Namun, disisi lain perusahan dengan leverage tinggi memiliki biaya agensi yang tinggi karena tingginya risiko yang mungkin terjadi (misal kesulitan keuangan) (Jensen \& Meckling, 1976). Lebih lanjut, Ousama, et al(2012) menyatakan bahwa kreditur dan pihak eksternal lainnya menuntut keterbukaan informasi lebih lanjut untuk mengurangi asimetri informasi. Dalam rangka meningkatkan kepercayaan para kreditur, maka mendorong perusahaan untuk mengungkapkan modal intelektualnya yang diharapkan dapat memberikan sinyal bahwa perusahaan memiliki value added, selain itu untuk memastikan keamanan dan keterjaminan pinjaman yang telah diberikan (Priyanti $\&$ Wahyudin, 2015).

Ketidak adanya hubungan antara leverage dan pengungkapan IC yang telah dibuktikan dalam penelitian ini tidak sejalan dengan teori agensi bahwa perusahaan yang memiliki leverage yang tinggi akan berdampak pada biaya keagenan yang tinggi pula, sehingga untuk mengurangi biaya yang tinggi yang diakibatkan karena adanya asimetri informasi ini perusahaan perlu untuk melakukan pengungkapan informasi yang lebih luas, termasuk modal intelektual. Pada penelitian Giacosa et al(2017) diungkapkan bahwa rendahnya pengungkapan modal intelektual, karena pertama, tujuan untuk mengembangkan modal intelektual adalah penciptaan nilai di dalam perusahaan daripada pelaporannya. Hal tersebut sesuai fakta bahwa investor cenderung menggunakan berbagai sumber informasi selain modal intelektual. Selain itu, perusahaan lebih tertarik manfaat modal intelektual untuk internal perusahaan daripada manfaat eksternal seperti pembiayaan tambahan. Hal lain yang juga menjadi pertimbangan bahwa manajer yang memahami kekuatan modal intelektual dapat memutuskan untuk tidak melaporkan sumber daya-nya kepada para pesaing. Selain informasi modal intelektual, laporan tanggung jawab sosial dan laporan keberlanjutan perusahaan telah menjadi pengungkapan sukarela utama. Sampai saat ini, di Indonesia belum memiliki aturan yang dapat memperkuat peran pengungkapan IC. Hal inilah yang menjadi salah satu alasan rendahnya pengungkapan IC pada perusahaan di Indonesia. Dengan demikian, leverage bukan merupakan faktor pendorong perusahaan untuk mengungkapkan modal intelektualnya pada laporan tahunan.

Hasil uji regresi menunjukkan bahwa secara statistik kinerja keuangan belum mampu memoderasi pengaruh umur perusahaan terhadap pengungkapan modal intelektual. Artinya perusahaan yang masih baru dan memiliki kinerja yang baik bukan merupakan faktor yang menyebabkan perusahaan mengungkapkan IC perusahaan semakin lengkap. Pada dasarnya, pengungkapan membutuhkan biaya. Salah satu sumber biaya adalah berdasarkan laba. Artinya, seharusnya perusahaan kecil yang memiliki profitabilitas yang tinggi akan meningkatkan ICDnya. 
Menurut teori biaya politik, semakin tinggi keuntungan yang dimiliki perusahaan menunjukkan semakin banyak sumber daya yang dapat digunakan oleh perusahaan untuk membuat lebih banyak pengungkapan. Hal tersebut ditunjukkan kepada pasar terkait sumber keuntungan yang dimiliki perusahaan. Namun, hasil penelitian ini menolak kerangka pemikiran ini. Kinerja keuangan yang ditunjukkan laba bersih per saham tidak mampu menjadi penentu kuat lemahnya pengaruh umur perusahaan terhadap pengugkapan modal intelektual. Dalam penelitian ini, terdapat indikasi bahwa profitabilitas perusahaan yang masih muda tidak digunakan sebagai sumberdaya untuk meningkatkan pengungkapan infomasi kinerjanya. Terdapat indikasi, penggunakan profitabilitas digunakan untuk menambah modal perusahaan.

Ousama, et al(2012) mengungkapkan bahwa perusahaan besar memiliki lebih banyak sumber daya. Pada era globalisasi ini, persaingan yang terjadi semakin ketat sehingga menuntut perusahaan memiliki keunggulan kompetitif seperti modal intelektual. Sumber daya yang dimiliki perusahaan yang besar tentunya lebih kompleks dibandingkan dengan perusahaan kecil yang sejenis. Perusahaan yang memiliki sumber daya yang besar berupa modal intelektual dan kinerja yang baik akan memiliki insentif yang mendorong untuk menyediakan informasi lebih banyak untuk meningkatkan kepercayaan investor dan menginginkan keunggulan kompetitif dibandingkan para pesaingnya.

Namun, hasil penelitian menunjukkan bahwa earning per share dapat memoderasi pengaruh ukuran perusahaan terhadap pengungkapan modal intelektual. Hal ini dapat diartikan bahwa perusahaan dalam mengungkapkan modal intelektual-nya dipengaruhi baik buruknya kinerja keuangan perusahaan. Purnomosidhi (2006) mengungkapkan bahwa besarnya biaya pengungkapan IC dan kemampuan perusahaan untuk menanggung biaya pengungkapan juga dipengaruhi oleh modal intelektual yang dimiliki. Perusahaan yang memiliki kemampuan modal intelektual yang rendah akan cenderung memutuskan untuk melakukan pengungkapan kepada publik atas modal intelektualnya. Hal ini sebagai salah satu solusi untuk meningkatkan atau mempertahankan reputasi perusahaan akibat menurunnya kinerja perusahaan.

Hasil uji regresi menunjukkan bahwa peran earning per share mampu memoderasi secara signifikan pengaruh rasio kepemilikan manajerial terhadap pengungkapan IC. Pengaruh kepemilikan manajerial terhadap pengungkapan IC secara langsung menunjukkan koefisien regresi yakni 0,464. Pengaruh kepemilikan manajerial terhadap pengungkapan modal intelektual yang dimoderasi kinerja keuangan menunjukkan koefisien regresi sebesar -0,5000. Hasil negatif membuktikan bahwa earning per share memperlemah pengaruh kepemilikan manajerial terhadap pengungkapan IC. Tingkat kepemilikan manajerial dengan kinerja keuangan yang baik akan menyebabkan semakin memperlemah pengungkapan modal intelektual yang dilakukan perusahaan. Kinerja keuangan diproyeksikan dengan laba bersih per saham (Earnings per Share/EPS), dimana semakin tinggi nilai EPS maka kinerja keuangan semakin baik.

Sesuai dengan teori agensi, peningkatan kepemilikan manajerial dapat mengurangi konflik yang terjadi antara prinsipal dan agen. Menurut Jensen \& Meckling (1976) adanya kepemilikan manajerial akan menyatukan kepentingan antara agen dan prinsipal sehingga pihak manajemen (agen) akan bertindak sesuai dengan yang diharapkan para pemegang saham. Penyatuan kepentingan yang terjadi inilah yang mampu mengurangi perilaku oportunistik manajer untuk mencapai kepentingan pribadi dengan cara mengungkapkan modal intelektual yang dimiliki perusahaan (Utama \& Khafid, 2015).

Perusahaan yang mempunyai kepemilikan manajerial yang tinggi pada perusahaan yang berkinerja baik akan mengurangi pengungkapan modal intelektual. Manajer akan memperhatikan aktivitas-aktivitas yang dilakukan perusahaan, ketika aktivitas tersebut dirasa penting dan mampu mendukung perusahaan maka perlu ditingkatkan, sedangkan akan mengurangi aktivitas yang dirasa tidak memberikan pengaruh secara signifikan terhadap perusahaan, salah satunya terkait pengungkapan informasi. Suwardjono (2014) menganggap bahwa pengungkapan informasi yang dilakukan perusahaan dapat menjadi penyebab perusahaan memiliki posisi yang kurang menguntungkan dan selanjutnya menjadi biaya bagi perusahaan. Selain itu, perusahaan perlu memutuskan apakah pengungkapan modal intelektual merupakan informasi yang relevan bagi para pemangku kepentingan. Informasi yang perlu diungkapkan terkait modal intelektual harus dipertimbangkan secara hati-hati untuk setiap jenis pemangku kepentingan karena infomasi yang relevan lebih baik daripada informasi yang berlebihan (Giacosa et al, 2017). Selain itu, alasan lain bahwa peningkatan kepemilikan manajerial dapat menyelaraskan kepentingan perusahaan dengan para pemangku 
kepentingan (Yarram \& Balachandran, 2015). Pengungkapan IC yang dilakukan secara hati-hati dimaksudkan sebagai salah strategi dalam persaingan untuk menghindari dimanfaatkannya informasi tersebut oleh para pesaing. Hal ini dapat menjadi alasan bagi perusahaan untuk mengurangi pengungkapan IC.

Hasil uji regresi menunjukkan bahwa secara statistik earning per share tidak mampu memoderasi secara signifikan pengaruh leverage terhadap pengungkapan modal intelektual. Kebutuhan yang semakin kompleks untuk mencapai keunggulan kompetitif dalam persaingan bisnis terutama beralihnya strategi bisnis menuju pengetahuan, maka perlu direspon oleh perusahaan, misal penggunaan teknologi atau pelatihan bagi karyawan. Dalam rangka memenuhi kebutuhan tersebut tidak jarang perusahaan memanfaatkan pinjaman dari pihak luar (kreditur).

Hubungan yang terjalin antara pihak perusahaan dengan kreditur dapat meningkatkan kompleksitas hubungan yang terjadi sehingga mampu meningkatkan biaya agensi. Dengan asumsi biaya agensi, perusahaan merupakan tempat atau titik pertemuan bagi berbagai jenis hubungan kontraktual, salah satunya adalah kontraktual antara perusahaan dengan kreditur (Bastian, 2006). Perusahaan yang memiliki tingkat hutang yang tinggi akan berdampak pada banyaknya pihak yang akan menilai kemampuan perusahaan dalam membayar kewajiban di masa yang akan datang. Selain itu perusahaan yang memiliki risiko bisnis yang rendah akan direspon secara positif oleh pasar. Risiko yang rendah ini dapat diartikan bahwa perusahaan memiliki kinerja keuangan yang baik yang mampu memberikan pengembalian pinjaman di masa yang akan datang. Perusahaan dengan kinerja keuangan yang baik akan melakukan pengungkapan lebih banyak dibandingkan dengan perusahaan yang berkinerja buruk seiring dengan timbulnya biaya pengungkapan yang terjadi. Namun, hasil dalam penelitian ini earning per share tidak mampu memoderasi pengaruh leverage terhadap pengungkapan modal intelektual.

\section{SIMPULAN}

Penelitian ini telah memberikan bukti empiris bahwa umur perusahaan, jumlah aset dan rasio kepemilikan manajerial memiliki pengaruh positif terhadap pengungkapan IC. Tingkat leverage tidak memiliki dampak pada pengungkapan IC. Kinerja keuangan yang diukur dengan profitabilitas mampu memoderasi pengaruh ukuran perusahaan dan kepemilikan manajerial terhadap pengungkapan IC, namun tidak memoderasi pengaruh umur perusahaan, dan leverage terhadap pengungkapan modal intelektual. Temuan profitabilitas mampu moderasi positif terhadap hubungan antara ukuran perusahaan dengan ICD mengindikasikan bahwa semakin besar ukuran perusahaan akan menyebabkan semakin luas ICD-nya. Hasil penelitian yang menemukan bahwa profitabilitas mampu memoderasi secara secara negatif terhadap hubungan kepemilikan manajerial dengan ICD mengindikasikan bahwa kepemilikan manajemen yang semakin besar akan menyebabkan menurunnya ICD.

Penelitian ini menggunakan perusahaan yang termasuk LQ 45 dengan alasan karena menggunakan proksi kinerja pasar untuk menjelaskan pengungkapan IC. Sehingga saran yang dapat diberikan bagi peneliti selanjutnya adalah mengganti objek penelitian perusahaan lain, seperti manufaktur, perbankan, high technology dan menggunakan variabel dengan proksi pengukuran lainnya. Saran ini diberikan karena pada perusahaan tersebut, tuntutan untuk menggunakan modal intelektual semakin besar.

\section{REFERENSI}

Abdolmohammadi, M. J. (2005). Intellectual capital disclosure and market capitalization. Journal of Intellectual Capital, 6(3), 397-416. https:// doi.org/10.1108/14691930510611139

Anderrson, A., \& Folkare, E. (2015). Company characteristics and voluntary disclosure of intellectual capital, (May), 1-60.

Asfahani, E. S. (2017a). Pengaruh Ukuran Perusahaan, Profitabilitas, Leverage, Umur Perusahaan dan Kepemilikan Pemerintah terhadap Pengungkapan Intellectual Capital. Jurnal Ekonomi Akuntansi, 3, 40-61.

Asfahani, E. S. (2017b). Pengaruh Ukuran Perusahaan, Profitabilitas, Leverage, Umur Perusahaan dan Kepemilikan Pemerintah Terhadap Pengungkapan Intellectual Capital. Jurnal Ekonomi Akuntansi, 3(3), 40-61.

Ashari, P. M. S., \& Putra, I. N. W. A. (2016). Pengaruh Umur Perusahaan, Ukuran Peusahaan, Profitabilitas, Leverage, dan Komisaris Independen terhadap Pengungkapan Modal Intelektual. E-Jurnal Akuntansi Universitas Udayana ISSN: 2302-8559, 14(3), 1699-1726.

Bastian, I. (2006). Akuntansi Pendidikan. Jakarta: Erlangga.

Bhasin, M. L. (2011). Disclosure of Intellectual Capital in Annual Reports/: An Empirical Study of the Indian IT Corporations. Modern 
Economy, 2(September), 455-467. https:// doi.org/10.4236/me.2011.24051

Bidaki, S., \& Hejazi, R. (2014). Effects of profitability on the Intellectual Capital Disclosure in listed Companies in Tehran Stock Exchange. International Journal of Education and Applied Sciences, 1(5), 248-255. https:// doi.org/10.5958/2229-4473.2016.00045.8

Bontis, N., Janoševiæ, S., \& Dženopoljac, V. (2015). Intellectual capital in serbia's hotel industry. International Journal of Contemporary Hospitality Management, 27(6), 1365-1384. https://doi.org/10.1108/IJCHM-12-2013-0541

Boujelbene, M. A., \& Affes, H. (2013). The Impact of Intellectual Capital Disclosure On Cost of Equity Capital/ : A Case of French Firms. Journal of Economics, Finance and Administrative Science, 18(34), 45-53.

Branco, M. C., Delgado, C., Sá, M., \& Sousa, C. (2010). An Analysis of Intellectual Capital Disclosure by Portuguese Companies. EuroMe Journal of Business, 5(3), 258-278.

Brüggen, A., Vergauwen, P., \& Dao, M. (2009). Determinants of intellectual capital disclosure: Evidence from Australia. Management Decision, 47(2), 233-245. https://doi.org/ 10.1108/00251740910938894

Camfield, C. G., Giacomello, C. P., \& Sellitto, M. A. (2018). The Impact of Intellectual Capital on Organizational Performance. Journal Technology Management \& Innovation, 13(2), 23-32. https://doi.org/10.1016/ j.sbspro.2016.05.106

Chahal, H., \& Bakshi, P. (2016). Measurement of Intellectual Capital in the Indian Banking Sector. The Journal for Decision Makers, 41(1), 6173. https://doi.org/10.1177/0256090916629253

Chu, S. K. W., Chan, K. H., \& Wu, W. W. Y. (2011). Charting Intellectual Capital Performance of The Gateway to China. Journal of Intellectual Capital, 12(2), 249-276. https://doi.org/10.1108/ 14691931111123412

Clarke, M., Seng, D., \& Whiting, R. H. (2010). Intellectual Capital and Firm Performance in Australia (Accountancy Working Paper Series No. 12). Retrieved from http:// hdl.handle.net/10523/1585

Eddine, C. O. H., Abdullah, S. N., Hamid, F. A., \& Hossain, D. M. (2015). The Determinants of Intellectual Capital Disclosure/ : a MetaAnalysis Review. Journla of Asia Business Studies, 9(3), 232-250. https://doi.org/10.1108/ JABS-03-2015-0028
Firer, S., \& Williams, S. M. (2005). Firm ownership structure and intellectual capital disclosures. South African Journal of Accounting Research, 19(1), 1-18. https://doi.org/10.1080/ 10291954.2005.11435116

Gheisari, T., \& Amozesh, N. (2016). Investigating the Effect of Intellectual Capital on the Value Creation of Companies Listed in Tehran Stock Exchange. Journal of Administrative Management, Education and Training, 12(3), 71-78.

Ghozali, I., \& Chariri, A. (2014). Teori Akuntansi Edisi 4. Semarang: Penerbit Universitas Diponegoro.

Harianto, S. (2012). Pengaruh Kepemilikan Manajerial, Komite Audit, Leverage, dan Umur Perusahaan terhadap Pengungkapan Modal Intelektual. Jurnal Akuntansi Dan Keuangan, 2, 89-101.

Hidalgo, R. L., Garcý'a-Meca, E., \& Martý'nez, I. (2011). Corporate Governance and Intellectual Capital Disclosure. Journal of Business Ethics, 100, 483-495. https://doi.org/10.1007/s10551010-0692-x

Hrp, R. A. P., Kristanti, F. T., \& Dillak, V. J. (2018). The Influence of Board Of Leverage, Profitability and Firm Size To Intellectual Capital Disclosure (Case Study On Banking Sector Companies Listed In Indonesia Stock Exchange In 2013 - 2016). In e-Proceeding of Management/ : (Vol. 5, pp. 504-511).

Jensen, M. C., \& Meckling, W. H. (1976). Theory of the firm: Managerial Behavior, Agency Costs and Ownership Structure. Journal of Financial Economics, 3(4), 305-360.

Kateb, I. (2014). The Determinants of Intellectual Capital Disclosure: Evidence From French Stock Exchange. International Journal of Accounting and Financial Reporting, 4(2), 628-646.

Lina. (2013). Faktor-Faktor Penentu Pengungkapan Modal Intelektual. Media Riset Akuntansi ISSN 2088-2106, 3(1), 48-64.

Mariana, S., Latif, R. A., \& Mustafa, N. H. (2011). The Determinants of Intellectual Capital Disclosure Among Malaysian Listed Companies. International Journal of Management and Marketing Research, 4, 2-10.

Maulida, A. (2013). Analisis Pengaruh Ukuran Perusahaan, Umur Perusahaan, Kepemilikan Publik, Profitabilitas, Dan Leverage Terhadap Tingkat Pengungkapan Intellectual Capital Pada Perusahaan Yang 
Terdaftar Di JII Tahun 2012-2013. Universitas Islam Negeri Sunan Kalijaga.

Meizaroh, \& Lucyanda, J. (2012). Pengaruh Corporate Governance, Kinerja Peusahan, dan Umur Perusahaan terhadap Pengungkapan Modal Intelektual. Media Riset Akuntansi ISSN 2088-2106, 2(1), 65-81.

Mitra, S., Abhilash, K. P. P., Arora, S., \& Miraclin, A. (2015). The Nature and Extent of Voluntary Intellectual Capital Disclosures by Australian and UK Biotechnology Companies. Journal of Vector Borne Diseases, 52(4), 281-286. https:/ /doi.org/10.1108/14691931011085669

Mukti, A. H., \& Istianingshih. (2018). The Impact of Ownership Structure on Intellectual Capital Disclosure. International Business Management, 12(3), 337-345.

Nany, M., \& Mujiyono. (2010). Pengaruh Leverage, Saham Publik, Size, dan Komite Audit terhadap Luas Pengungkapan Sukarela. Jurnal Dinamika Akuntansi, 2(2), 129-134.

Noradiva, H., Parastou, A., \& Azlina, A. (2016). The Effects of Managerial Ownership on the Relationship between Intellectual Capital Performance and Firm Value. International Journal of Social Science and Humanity, 6(7), 514-518. https://doi.org/10.7763/ IJSSH.2016.V6.702

Nugroho, A. (2012). Faktor-faktor yang Mempengaruhi Intellectual Capital Disclosure (ICD). Accounting Analysis Journal, 1(2), 1-11.

Nuryaman. (2009). Pengaruh Konsentrasi Kepemilikan, Ukuran Perusahaan, dan Mekanisme Corporate Governance terhadap Pengungkapan Sukarela. Jurnal Akuntansi Dan Keuangan Indonesia, 6(1), 89-116.

Ousama, A. A., Fatima, A. H., \& Majdi, A. R. H. (2012). Determinants of Intellectual Capital Reporting Evidence from Annual Reports of Malaysian Listed Companies. Journal of Accounting in Emerging Economies, 2(2), 119-139. https://doi.org/10.1108/ 20421161211229808

Prasinta, D. (2012). Pengaruh Good Corporate Governance terhadap Kinerja Keuangan. Accounting Analysis Journal ISSN 22526765, 1(2), 2-7.

Priyanti, S. Y., \& Wahyudin, A. (2015). Determinan Pengungkapan Modal Intelektual Berdasarkan Variabel Keuangan dan Non Keuangan. Accounting Analysis Journal, 4(2), 1-10.

Purnomosidhi. (2006). Praktik Pengungkapan Modal Intelektual pada Perusahaan Publik di BEJ.
Jurnal Riset Akuntansi Indonesia, 9, 1-20.

Reditha, D., \& Mayangsari, S. (2016). Faktor-Faktor yang Mempengaruhi Pengungkapan Modal Intelektual. Media Riset Akuntansi, Auditing \& Informasi, 16, 1-24.

Robert, K., \& Angelo, K. (2014). Perilaku Organisasi Edisi 9. Jakarta: Salemba Empat.

Sardo, F., \& Serrasqueiro, Z. (2018). Intellectual Capital, Growth Opportunities, And Financial Performance In European Firms Dynamic Panel Data Analysis. Journal of Intellectual Capital, 19(4), 747-767. https://doi.org/10.1108/JIC-072017-0099

Sari, H. M., \& Andayani. (2017). Pengaruh Kinerja Intellectual Capital, Leverage, dan Size terhadap Pengungkapan Intellectual Capital. Jurnal Ilmu Dan Riset Akuntansi ISSN: 2460-0585, 6(1).

Seetharaman, A., Sooria, H. H. B. Z., \& Saravanan, A. S. (2002). Intellectual Capital Accounting and Reporting in the Knowledge Economy. Journal of Intellectual Capital, 3, 128-148.

Stropnik, N., Korošec, B., \& Tominc, P. (2017). The Relationship Between the Intellectual Capital Disclosure and Cost of Debt Capital - A Case of Slovenian Private Audited Organisations. Naše Gospodarstvo/Our Economy, 63(4), 316. https://doi.org/10.1515/ngoe-2017-0019

Sudibyo, A. A., \& Basuki, B. (2017). Intellectual capital disclosure determinants and its effects on the market capitalization/ : evidence from Indonesian listed companies. SHS Web of Conference 34, 07001, 1-7.

Suhardjanto, D., \& Wardhani, M. (2010). Praktik Intellectual Capital Disclosure Perusahaan yang Terdaftar di Bursa Efek Indonesia. Jurnal Akuntansi Dan Akuntansi Indonesia, 14(1), 71-85.

Sumedrea, S. (2013). Intellectual Capital and Firm Performance/: A Dynamic Relationship in Crisis Time. Procedia Economics and Finance, 6(13), 137-144. https://doi.org/10.1016/S22125671(13)00125-1

Suparno, \& Ramadini, R. (2017). Pengaruh Intellectual Capital dan Earning PerShare terhadap Nilai Perusahaan ( Studi Empiris pada Perusahaan LQ45 yang Terdaftar di Bursa Efek Indonesia Periode 2010-2014 ). Jurnal Manajemen Dan Keuangan, 6(1), 710-718. https://doi.org/10.1371/journal.pone.0083491

Suwardjono. (2014). Teori Akuntansi Perekayasaan Pelaporan Keuangan Edisi Ketiga. Yogyakarta: BPFE Yogyakarta. 
Suwarjuwono, T., \& Kadir, P. A. (2003). Intellectual Capital: Perlakuan, Pengukuran, dan Pelaporan (Sebuah Library Research). Jurnal Akuntansi Dan Keuangan, 5, 35-57.

Suwart, T., Mindarti, C. S., \& Setianingsih, N. (2016). Analisis Pengaruh Komisaris Independen, Konsentrasi Kepemilikan Terhadap Intellectual Capital Disclosure (ICD) Dan Kinerja Perusahaan. In Managing Local Resources to Compete in the Global Market - Forum Manajemen Indonesia VIII (pp. 1-18). Palu: Forum Manajemen Indonesia.

Taliyang, S. M., Abdul Latif, R., \& Mustafa, N. (2011). The determinants of intellectual capital disclosure among Malaysian listed companies. International Journal of Management and Marketing Research, 4(3), 25-33.

Ting, I. W. K., \& Lean, H. H. (2009). Intellectual Capital Performance of Financial Institutions in Malaysia. Journal of Intellectual Capital, 10(4), 588-599. https://doi.org/10.1108/ 14691930910996661

Utama, P., \& Khafid, M. (2015). Faktor-Faktor yang Mempengaruhi Luas Pengungkapan Modal Intelektual pada Perusahaan Perbankan di BEI. Accounting Analysis Journal, 4(2), 1-10.

Utami, E. M. (2018). The Intellectual Capital Components on Firm Value/ : Evidence from LQ-45 Index Companies. Jurnal Keuangan Dan Perbankan, 22(2), 291-300.
W, I. F. S., \& Firmansyah, R. (2012). Immunodiagnosis of asymptomatic malignant lymphomas. Jurnal Dinamika Akuntansi, 4(1), $1-12$.

Wedari, L. K. (2016). Intellectual capital dan intellectual capital disclosure terhadap market performance pada perusahaan publik indeks LQ-45. Jurnal Akuntansi \& Auditing Indonesia, 20(1), 27-36.

Woodcock, J., \& Whiting, R. H. (2009). Intellectual Capital Disclosures by Australian Companies. In AFAANZ Conference (pp. 1-31). https:// doi.org/10.1016/j.adiac.2012.03.004

Yarram, S. ., \& Balachandran, B. (2015). Managerial Ownership and Corporate Performance: Evidence from Malaysia. Proceedings of the 2nd International Conference on Corporate Governance, 187-206.

Yosano, G. R. C. N. T. (2009). Intellectual Capital Disclosures in Japanese IPO prospectuses. Journal of Human Resource Costing \& Accounting, 13(4), 316-337. https://doi.org/ 10.1108/14013381011010150

Yudhanti, C. B. H., \& Josepha C Shanti. (2011). Intellectual Capital dan Ukuran Fundamental Kinerja Keuangan Perusahaan. Jurnal Akuntansi Dan Keuangan, 13(2), 57-66. https://doi.org/10.1002/hed.23537

Zehri, C., Abdelbaki, A., \& Abdelbaki, A. (2012). How Intelectual Capital Affects A Firm's Performance? Australian Journal of Business and Management Research, 2(08), 24-31. 